\section{DIGITAL COMMONS \\ @ UNIVERSITY OF SOUTH FLORIDA}

Journal of Practitioner Research

\title{
Using Embodied Practices with Preservice Teachers: Teaching and Reflecting Through the Body to Re-think Teacher Education
}

\author{
Emily Klein \\ Montclair State University, kleine@montclair.edu \\ Monica Taylor \\ Montclair State University, taylorm@montclair.edu \\ Rachel Forgasz \\ Monash University, rachel.forgasz@monash.edu
}

Follow this and additional works at: https://digitalcommons.usf.edu/jpr

Part of the Education Commons

\section{Recommended Citation}

Klein, Emily; Taylor, Monica; and Forgasz, Rachel (2019) "Using Embodied Practices with Preservice Teachers: Teaching and Reflecting Through the Body to Re-think Teacher Education," Journal of Practitioner Research: Vol. 4 : Iss. 2 , Article 4. https://doi.org/10.5038/2379-9951.4.2.1088

Available at: https://digitalcommons.usf.edu/jpr/vol4/iss2/4

This Practitioner Research is brought to you for free and open access by the Open Access Journals at Digital Commons @ University of South Florida. It has been accepted for inclusion in Journal of Practitioner Research by an authorized editor of Digital Commons @ University of South Florida. For more information, please contact digitalcommons@usf.edu. 


\title{
Using Embodied Practices with Preservice Teachers: Teaching and Reflecting Through the Body to Re-think Teacher Education
}

\begin{abstract}
This action research study describes how three teacher educators invited preservice teachers to be in their bodies, or learn through "embodied pedagogy." We wanted see how this pedagogy helped preservice teachers learn to reflect through their bodies, confront their own bias to cognitive ways of knowing, and ultimately begin to consider the use of embodied instructional strategies. We describe our questions, the activities we designed to help us answer them, and data collected from the first course in a pre-service teacher education program. Finally, we analyze these data and identify themes related to embodied learning and reflection, and describe some potential implications for teacher educators. Although at times uncomfortable, we found the body became a tool for reflection whether through experiencing or accessing emotions, or for uncovering new meanings and deep insights about themselves.
\end{abstract}

Sometimes I feel like a data machine. (Preservice teacher)

In the past decade, the teacher education and preparation landscape has shifted towards increased accountability focused on data driven assessments. In the United States and Australia preservice teachers themselves are increasingly being called upon to pass standardized assessments demonstrating their ability to collect and analyze data about students (Mandinatch \& Jimerson, 2016; Reeves, Summers, \& Grove, 2016; van Geel, Keunin, Visscher, \& Fox, 2016). While we too value using deep analysis of students' work to guide instruction, we also believe that too often traditional teacher education practices privilege language, reasoning, and thought over embodied knowing. This manifests in how teacher educators instruct preservice teachers, design and evaluate assignments, and engage with their students through observations and critique. Traditional teacher education favors positivist assessments whether through standardized gatekeeping for teacher certification or requiring teachers to develop curriculum that prepares K-12 students for standardized tests. However, the authors are well aware that we bring our whole selves into teaching (Taylor \& Coia, 2009) and in doing so we develop relationships with our students and co-construct meaning with them. If we believe this to be true then it has implications for what we do in preservice teacher education.

What happens when we use action research as a methodological framework to enact "embodied pedagogy as learning that joins body and mind in 
a physical and mental act of knowledge construction" (Nguyen \& Larson, 2015, p. 332) with preservice teachers right at the start of their initial teacher education? This action research describes how three teacher educators invited preservice teachers to be in their bodies. We did this in order to theorize about how teaching and learning influences the ways in which preservice teachers learn to reflect through their bodies, confront their own bias to cognitive ways of knowing, and ultimately begin to consider the use of embodied instructional strategies.

Embodied teacher education practices offered our students some tools to begin to explore who they are becoming as teachers through emotions and the body.

\section{Review of Literature}

\section{Embodied Pedagogies}

There is general agreement amongst researchers of embodied pedagogies that many Western formal education systems privilege cognitive forms and ways of knowing (see, for example, Forgasz, 2015; Lawrence, 2012; Satina \& Hultgren, 2001). According to Estola and Elbaz-Luwisch (2003), predilection for the dictates of Cartesian dualism explains the historical privileging of mind over body, while the reduction of the body to discourse in much postmodern philosophy perpetuates the problem in more contemporary thought. Senior and Dixon (2009) concur and, writing about teacher education in particular, they argue that "[t]here is a silence" (p. 24) in the research literature and a "virtual abandonment of our bodies in pedagogy" (p. 24) in most teacher education programs. Like Estola and Elbaz-Luwisch (2003), they attribute this silence to the precepts of both Cartesian dualism and the postmodern repositioning of the body in and through discourse, such that "its materiality is lost" (p. 24).

In recent years there has been increasing interest in embodied teaching, learning, and pedagogy across all educational sectors. In the compulsory schooling years, neuroscientific understandings of mind-body connections have seen increased focus on how embodiment can service students' deeper cognition (Ardoy, Fernandez-Rodriguez, Jimenez-Pavon, Castillo, Ruiz, Ortega, 2014; Chen, Yan, Yin, Pan, \& Chang, 2014; Gao, Hannon, Xiang, Stodden, \& Valdez, 2013). In higher education, interest in embodied learning has arisen at least partly in response to the appreciation of "direct, experiential engagement as an alternative way to construct knowledge" (Freiler, 2008, p. 43), especially for adult learners. Finally, embodiment is of interest across educational settings because it accounts for the relational connection between teachers and learners in real time and space (Dixon \& Senior, 2011; MacIntryre Latta \& Buck, 2008; Senior \& Dixon, 2009). 
Forgasz and McDonough (2017) observe that in the teacher education research literature, "the term embodied pedagogy is invoked in slightly different ways to emphasize different nuances of its nature, relevance and value" (p. 54). For example, Estola and Elbaz-Luwisch (2003) take a phenomenological view of the significance of bodies and embodiment in teaching, citing Merleau-Ponty's active, agentic, and intentional body. They draw further from the Finnish concept of "positions of bodies to study how people experience the world and how they live and act in different practices as embodied" (p. 699). They are especially interested in the embodied person of the teacher and seek "new insight on the practice of teaching as an embodied activity" (p. 699). For Senior and Dixon (2009), however, such research interests represent "reductionist understandings of embodied learning or embodied teaching" (p. 25). For them, embodied pedagogy is about locating the learning that happens with and between bodies. They explain: "the pedagogical relationship between self and other is not metaphorical. It is not only that the learning and teaching are bodily, but the form of the relationship is bodily" (Dixon \& Senior, 2011, p. 482). For others, still, embodied pedagogy is about the role of the body in knowledge construction. For example, Freiler (2008) is interested in repositioning "the body from a place of otherness into practicing space where both the body and mind are being more holistically approached and valued" (p. 45). Nguyen and Larson (2015) similarly advocate the effectiveness of embodied learning that joins "body and mind in a physical and mental act of knowledge construction" (p. 332).

In this research, we remained open to all of these conceptions of embodied teaching, learning, and pedagogy. Like Forgasz and McDonough (2017), we too "acknowledge the overlap and the sometimes inseparable, intermingling notions of embodied teaching, embodied learning, and the embodied dynamic of the pedagogical relationship between teaching and learning as it is lived through the bodies of teachers and learners" (p. 55). Indeed, in our findings, we identified moments of insight from our students in relation to all of them-appreciation of the teacher as embodied, of the role of the body and the emotions in knowledge construction, and of the pedagogical relationship as one that is lived and experienced in the space between teacher and learners. 
In this regard, we found Freiler's (2008) definitions of embodiment and embodied learning particularly helpful:

[E]mbodiment is defined as a way to construct knowledge through direct engagement in bodily experiences and inhabiting one's body through a felt sense of being-in-the-world. It also involves a sense of connectedness and interdependence through the essence of lived experiencing within one's complete humanness, both body and mind, in perceiving, interacting, and engaging with the surrounding world. Simply stated, embodied learning involves being attentive to the body and its experiences as a way of knowing. (p. 40)

\section{Methodology}

We used an action research methodology, a specific form of practitioner research, to examine our embodied teacher education practices and how they affect students' experiences and their ability to make sense of the complex, dynamic understandings of themselves as teachers and learners. We asked the following: What happens when we use action research as a methodological framework to enact embodied pedagogy with preservice teachers right at the start of their initial teacher education? We chose action research because as McNiff (2010) describes, this methodology focuses on "finding ways to improve your practice and then explaining how and why you have done so" (p. 6). We were attempting to both develop effective embodied teacher education practices and understand how those we used were encouraging our students as preservice teachers to reflect using their emotions and bodies. Action research involves those who "have a stake in the problem under investigation" and "connotes 'insider' research done by practitioners using their own site . . . and is deliberately and systematically undertaken and generally requires that some sort of evidence be presented to support assertions" (Anderson, Herr, \& Nihlen, 2007, pp. 2-3). While much of the literature on action research focuses on its role in K-12 classrooms, it has similar benefits for teacher educators. As in K-12 schools, when teacher educators conduct action research on practices with or for preservice teachers, they have opportunities to deeply reflect on and analyze their practice in systematic ways (Ginns, Heirdsfield, Atweh, \& Watters, 2001; Smith $\&$ Sela, 2005), make connections between theories and practice based knowledge (Ginns, Heidsfield, Atweh, \& Watters, 2001; Gitlin, Barlow, Brubank, Kauchak, \& Stevens, 1999; Price, 2001; Somekh \& Zeichner, 2009), and develop insider/practitioner knowledge about those practices that builds a collective knowledge base (Goodnough, 2010, Mertler, 2011). 
Specifically, our action research involved: "Identifying an area of focus, Collecting data, Analyzing and interpreting data, and Developing a plan of action" (Mills, 2011, p. 5). In truth, however, it did not feel like clean, neat steps of a recipe. Rather our action research felt more like "an ongoing spiral where reflection and data gathering lead to a plan of action that it is implemented" (Herr, 1999, p. 11). Our iterative research process was messy, recursive, and dynamic as we attempted to study our teaching as we were in the process of putting practices into place.

\section{Setting and Participants}

The setting for this study was a large public American university in the Northeast where two of the authors worked in the graduate program for preservice education. Participants were 18 secondary level preservice teachers enrolled in a Masters level dual certification education program. Students were studying to become K-12 content area teachers with a second certification in teaching students with disabilities. This was their first course in the program. It took place over two weekends and served as a 1-credit orientation program. The goals of this course were to lay the foundational ideas and concepts that underlie our program's commitment to social justice, equity, inquiry based pedagogy, and fostering inclusive classroom settings. Students read a series of important texts from Dewey (1938), Freire (1970), and Vygotsky (1978), Ladson-Billings (1995), and Noguera (2003). Course time was spent in meaning making activities that allowed students to dive deeply into the readings and concepts. Students also engaged in a series of activities that invited them to understand themselves as learners, explore critical learning incidents from their pasts, and examine the implications for themselves as future teachers.

\section{Activities}

Two of us (teacher educators in the United States) began to discuss with the third (Forgasz), a scholar doing work in areas of embodied teaching and learning, our desire to think about ways we might engage our students in embodied teaching and learning. We wondered if that might influence how they began to take on their teacher identities and the ways in which they reflected about teaching and learning. This concern led us to construct a focused embodied experience. We wanted to examine what happened and think about how this experience could inform our work with teachers. When we are involved in the work of developing teachers, there is often little time for faculty to engage in a leisurely process of collecting and analyzing data, but this study afforded us a 
space to deliberately implement strategies and reflect on students' meaning making (Herr, 1999).

Our action research provided a snapshot that focused on the "Developing a Professional Teacher Identity" embodied reflection activity during the first class where the preservice teachers examined their own notions and experiences of being a student and a teacher. They began by constructing bodily images or poses of their conceptions of being first a teacher and then a student. For example, some of the student images were: sitting slumped at a desk with a bored look on their face, typing on a computer keyboard while staring into a screen, or looking up at the teacher with wide open eyes. For teacher poses, we saw standing at a board and writing notes, reading from a book to group, or kneeling down next to a student to be at eye level. Figures 1 and 2 below provide an example of a student image and a teacher image. They created these images individually but then were asked to group themselves with others who shared similar images, in order to reflect on common understandings. They then were invited to move their bodies from their image as a student to their image as a teacher and then back to their student image. This was an opportunity for them to feel in their body what the transformation might be like. Preservice teachers videoed one another performing the transformation of their bodies and partners were able to witness and share what they noticed. Throughout the activity, they were asked to reflect on how the different images felt in their bodies. At the end of the two-session course as a final self-evaluation, students were asked to respond to a series of reflective prompts including one about what they had learned about embodied teaching and learning.

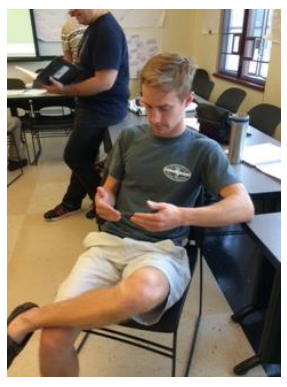

Figure 1. Student Image

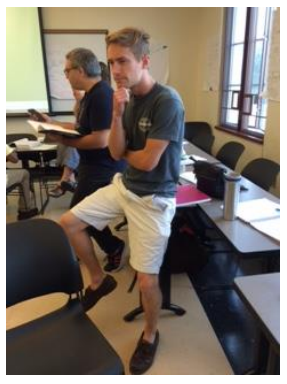

Figure 2. Teacher Image

\section{Data Sources}

Our data collection helped us to collect snapshots of (1) learning through the body and (2) the possibility of using the body to teach. Aligned with Anderson, Herr, and Nihlen's (2007) precepts for rigor in practitioner research, 
we wanted to triangulate the data by "inclusion of multiple perspectives" in order to guard "against viewing events in a simplistic or self-serving way" (p. 16). Specifically, our codes were solidified once we noticed that they appeared in the data across multiple preservice teachers and emerged frequently.

Data sources included student reflections as a part of their regular course work requirements and field notes taken by a doctoral student and a faculty participant observer. The guiding questions for the reflections were:

Please answer these prompts in narrative format using multiple complete sentences. Be as thorough and specific in your responses as possible. Give examples and/or refer to texts that we read. You may use a combination of narrative, embodied images (photos), even poetry, art, and music. Be creative!

1. What are some of the important take-aways from this two day course? (provide as many as possible and be descriptive)

2. What new realizations have you had about yourself as a learner and your history in schools?

3. How do these realizations help you think about what kind of teacher you want to be?

4. In particular how did or didn't using embodied reflective practices influence your thinking?

These reflections occurred both at the end of the first day's work and during final reflections of the course. We triangulated data across participants and across both data sources, noticing when a code or category emerged over and over again for various preservice teachers. Our field notes were used to confirm categories rather than to add to a code's data sample collection. This process allowed us to find a preponderance of evidence across participants as we demonstrate in our findings section.

We note the limitations of trying to describe the body's ways of knowing through the inherently limited means of language. Using reflective writing to provide access to students' meaning making was illuminating, but remains fundamentally insufficient. Interestingly, we did offer students the possibility to include art, photography, and poetry as options for writing their final reflections, but most chose to use traditional narratives as their reflective tool. 


\section{Data Analysis}

Each of the three researchers began by reading all the data and marking the margins for codes related to our research questions. Next, we met as a team to share our initial codes and begin to align our understanding of these data. Categories were generated both from our understanding of the themes within the literature as well as from the data themselves (thus we used a mix of both inductive and deductive analysis). We created a data analysis chart with overarching categories and examples from the preservice teachers' written reflections across participants (Table 1). We used our field notes to confirm emerging codes. For example, we created one sub-code about discomfort and we then added to this chart all the instances where participants noted discomfort engaging in using the body as a means of understanding themselves as learners and teachers. Once we had our data organized in this way we were able to write about the themes, weaving together the longer descriptive narrative samples of our preservice teachers. We have intentionally included these longer paragraphs as we want the themes to be illustrated in the authentic words of our students, so that we are showing rather than telling what we have found. Through our joint writing, questioning, and commentary in a collaborative word document, we were able to consolidate our categories and their meaning. This article is the final iteration of this collaborative meaning making and a composite of our preservice teachers' experiences.

Table 1

Sample Data Analysis Chart

\begin{tabular}{lll}
\hline $\begin{array}{l}\text { Category I } \\
\text { Code }\end{array}$ & Data Sample & Possible Sub-Code \\
\hline $\begin{array}{l}\text { Learning } \\
\text { through the } \\
\text { Body }\end{array}$ & $\begin{array}{l}\text { I've always thought of myself as a } \\
\text { pretty introspective person, but this } \\
\text { class allowed me to explore parts of } \\
\text { myself that either I didn't know } \\
\text { existed or hadn't bothered to analyze. }\end{array}$ & Reflection \\
\hline $\begin{array}{l}\text { Learning } \\
\text { through the }\end{array}$ & $\begin{array}{l}\text { Furthermore, this embodiment activity } \\
\text { truly impressed upon me the necessity } \\
\text { Body }\end{array}$ & $\begin{array}{l}\text { of reflection as a way of understanding } \\
\text { myself in relation to the world around } \\
\end{array}$ \\
& $\begin{array}{l}\text { me-in other words, the here and now. } \\
\text { Immediately after this activity my } \\
\text { reflection testifies to this process: }\end{array}$ & \\
\hline
\end{tabular}




\begin{tabular}{|c|c|c|}
\hline $\begin{array}{l}\text { Learning } \\
\text { through the } \\
\text { Body }\end{array}$ & $\begin{array}{l}\text { This exercise also got me out of my } \\
\text { comfort zone in a way I would have } \\
\text { never imagined. }\end{array}$ & Comfort/Discomfort \\
\hline $\begin{array}{l}\text { Embodied } \\
\text { Practices }\end{array}$ & $\begin{array}{l}\text { I appreciated how everyone else really } \\
\text { committed to the exercise- it definitely } \\
\text { made for a much better and more open } \\
\text { learning experience. }\end{array}$ & $\begin{array}{l}\text { Building } \\
\text { Community }\end{array}$ \\
\hline $\begin{array}{l}\text { Learning } \\
\text { through the } \\
\text { Body }\end{array}$ & $\begin{array}{l}\text { Although I was not the most } \\
\text { comfortable completing it, it allowed } \\
\text { me to see that what I am attempting to } \\
\text { display can often be different than } \\
\text { what is being observed. }\end{array}$ & Discomfort \\
\hline $\begin{array}{l}\text { Learning } \\
\text { through the } \\
\text { Body }\end{array}$ & $\begin{array}{l}\text { It was helpful to have someone } \\
\text { analyze your movements to help you } \\
\text { understand that you simply aren't } \\
\text { always displaying the language you } \\
\text { think you are and it can be difficult to } \\
\text { control as different individuals may } \\
\text { read it differently as well. }\end{array}$ & New Meanings \\
\hline $\begin{array}{l}\text { Learning } \\
\text { through the } \\
\text { Body }\end{array}$ & $\begin{array}{l}\text { The biggest personal take away I had } \\
\text { from these exercises was that myself } \\
\text { as a student is in direct conflict with } \\
\text { myself as a teacher. As a student, I am } \\
\text { very regimented, physically rigid, and } \\
\text { rarely view my accomplishments as } \\
\text { "enough." This rigid notion of what it } \\
\text { means and can look like to be a student } \\
\text { is exactly what I want to break through } \\
\text { as a teacher. However, I did not } \\
\text { recognize that I embody this myself } \\
\text { every day through my trombone } \\
\text { practice and personal studies. }\end{array}$ & New Realizations \\
\hline $\begin{array}{l}\text { Using the Body } \\
\text { to Teach }\end{array}$ & $\begin{array}{l}\text { Without this course, I don't think I } \\
\text { would have reflected on the ways that } \\
\text { teaching affects body language, or } \\
\text { emotions. This is one detriment of } \\
\text { learning how to teach in a classroom - } \\
\text { maybe it doesn't prepare you for the } \\
\text { use of your body or the way you'll feel } \\
\text { while teaching. }\end{array}$ & $\begin{array}{l}\text { Body language or } \\
\text { emotions }\end{array}$ \\
\hline
\end{tabular}




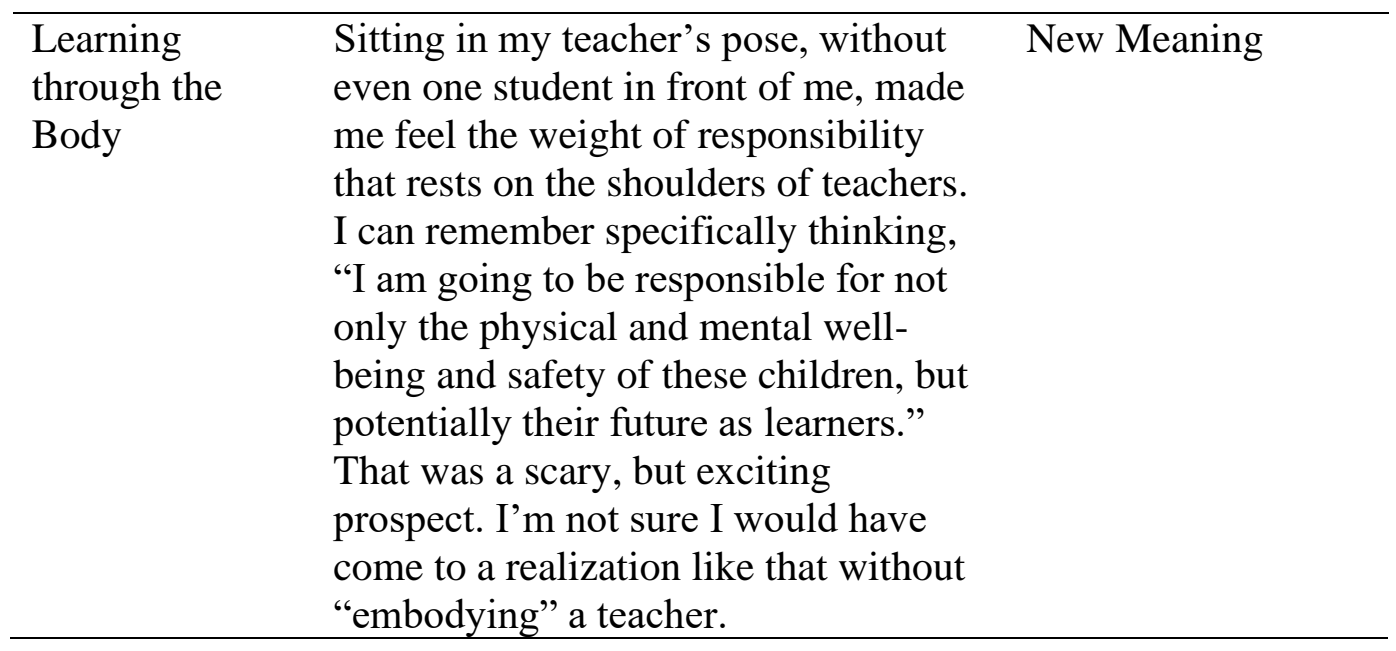

\section{Findings}

\section{Learning Through the Body}

The theme of learning through the body emerged from data codes describing how the preservice teachers learned when asked to use their bodies to create images of their "student" and "teacher" selves as part of the "Developing a Professional Teacher Identity" activity. Although at times uncomfortable, their bodies became a powerful reflective tool for the preservice teachers, whether by enabling them to experience or access emotions, or by supporting them to uncover new meanings and deeper insights about themselves. Related to our students' experiences of their body's role in knowledge construction, these data largely reflect the kinds of ideas about the nature and value of embodied learning advanced by Nguyen and Larson (2015), Freiler (2008), and Forgasz (2014, 2015).

Reflection. An essential goal of teacher education programs is to support reflection, of, on, and in practice, as a means of helping teachers make change and improve (Richardson, 1990). While the current paradigm of reflection focuses solely on data, we felt one important aspect of learning that emerged from the "Developing a Professional Teacher Identity" embodied activity was how the experience supported our students to appreciate the importance of reflection. This was evident when one student reflected, "I've always thought of myself as a pretty introspective person, but this class allowed me to explore parts of myself that either I didn't know existed or hadn't bothered to analyze." The body became a potent vehicle for reflection throughout the class as students began to realize that in preparing to become a teacher, they cannot separate, as one student 
reflected, their "own experiences and self from the act of teaching." In this sense, our students' experiences are similar to those of Forgasz's (2015) students for whom "[e]mbodiment offered a different way of accessing, and expressing, selfunderstanding" (p. 129) compared with the cognitive and discursive forms of reflective inquiry with which they were familiar.

The literature in teacher education emphasizes the importance of reflection as a tool for supporting teacher learning (Loughran, 2002) and we saw the importance and power of embodied learning as a way to support our students' reflective process. Our students also came to appreciate the value of learning through embodied reflection, a concept that many had not previously considered. As one preservice teacher wrote, "The concept that learning is influenced by aspects of the body beyond the brain makes a great deal of sense to me." One student explained: "This embodied activity truly impressed upon me the necessity of reflection as a way of understanding myself in relation to the world around me-in other words, the here and now." Pagis (2009) writes that, in the case of embodied reflection, "self-knowledge is anchored in bodily sensations" (p. 265). Perhaps it was the sense of being in the body that helped to ground this student in relation to others, pulling them into the present and working to support their reflective capacity as it involved them in the world. Being in the body helped somehow to trigger knowledge of self and others, perhaps in how (as we describe later) it connected learners to their emotional selves. Inviting preservice teachers to explore and express their self-concept through their bodies, first as students and then as teachers, offered a new way for them to reflect and to activate their past and future selves.

For many of our students, their "physicality" and "body" became texts of their past to investigate. They reflected that the embodied practices helped them think beyond just the instructional strategies they would use in the classroom to a more holistic identity shift of becoming a teacher. One preservice teacher emphasized "my physicality and how I move my body . . . all have substantial impact on my day to day teaching life, and, in turn, the experiences the experiences my students have with me as their teacher." As this comment suggests, participating in embodied experiences invited preservice teachers to reflect on larger and more complex questions around becoming a teacher, rather than the more common way of framing reflection in teacher education that often focuses on finding solutions to teaching problems (Fendler, 2003). Being in their bodies allowed students to begin to engage in what Schon (1995) calls "problem setting and intuitive artistry" in light of "situations of uncertainty, complexity, uniqueness, and conflict" (p. 29). This could be considered a shift away from thinking of teaching through a technical lens to framing teaching as a complex, 
moral, and human endeavor which involves the whole person and requires exploring the "muddiness of uncertainty" (Coia \& Taylor, 2017).

Discomfort: Part of the experience of using the body for learning is that it can be uncomfortable. Students mentioned experiencing discomfort as they moved out of traditional cognitive modes of learning and became open to learning in their body. One noted that:

This exercise also got me out of my comfort zone in a way I would have never imagined. As someone who is rather introverted I was initially wary about the idea of posing in front of virtual strangers. But as soon as we all stepped out into the open space between the desks I realized how similarly everyone else must have felt and suddenly my fear began to dissipate.

The wariness described by this student is unsurprising given that in higher education in general, there is a disembodied approach to teaching and learning (Lawrence, 2012), and in teacher education more specifically (MacIntyre Latta \& Buck, 2008). The comment also suggests that, despite experiencing discomfort, somehow our students continued to feel safe in this unfamiliar learning environment. Like Forgasz (2014), we observed that "far from creating an unsafe environment, the embodied aesthetic space ... offered [our students] an access point for reflecting" (p. 284). We began to consider the importance of scaffolding students through this unfamiliar form and way of knowing and about the importance of offering carefully structured and skillfully facilitated activities.

We saw consistent discussion of discomfort throughout the reflections and this led us to wonder about the potential importance of emotional experience as a dimension of embodied learning. We pondered whether provoking disequilibrium in our students was, in fact, supporting their learning through embodiment. Forgasz and McDonough (2017) argue that "[i]f its tendency to elicit vulnerability is a challenge of working with embodied pedagogies, so too is it a strength" ( $p$. 61). Their view aligns with literature on teacher learning which notes the importance of engaging preservice teachers in experiences that provoke unease and disequilibrium (see, for example, Cutri \& Whiting, 2015; Zembylas, 2010). Researchers identify the experience of "cognitive dissonance," where what teachers believe they know and can do, conflicts with new knowledge or experiences, as an important component of teacher change (Opfer \& Pedder, 2011). Experiences that challenge our sense of coherence and order, that throw us "off kilter" are referred to "as the 'edge of chaos,' or the special balance point between chaos and order where creativity and change can occur ..." (Opfer \& Pedder, 2011, p. 388). 
Straddling this "edge of chaos" may be why our students who wrote so frequently about their discomfort also wrote alongside this of their powerful learnings:

Although I was not the most comfortable completing it, it allowed me to see that what I am attempting to display can often be different than what is being observed. When working one on one with a partner . . . it was helpful to have someone analyze your movements to help you understand that you simply aren't always displaying the language you think you are and it can be difficult to control as different individuals may read it differently as well.

Another student said, “Although the instructor's enthusiasm was infectious, I found this exercise to be difficult and uncomfortable. I have never been comfortable in front of a camera and dislike acting. However, the points that were made were well-received and it did make me reflect internally in ways that I hadn't before." These insights suggest that the discomfort students experienced may have heightened their sensitivity to what they were thinking and feeling, thereby inducing a powerful experience that invited them to think deeply about their past experiences as learners. The body became a kind of text that invited students first to feel deeply into their past - and future - selves and then to be witnessed by others in what Forgasz and McDonough (2017) describe as the embodied pedagogical process of "feeling and seeing our way into knowing" ( $p$. 58). Engaging others in the process supported our students' embodied learning as they reflected back to one another about what was being conveyed. Our students' experiences of learning through their bodies reflects Dixon and Senior's (2011) sense of the interconnectedness of body and emotion in how we read one another, and of the notion that there exists a physical space between teaching and learning that is the pedagogical encounter.

New realizations. Frequently, the preservice teachers reflected on new realizations they were able to have through embodied work. Many wrote about "aha" moments they had in tying reflections about their experience as learners to their future selves as teachers. For teacher educators, this is particularly important as we know the power of the "apprenticeship of observation" (Lortie, 1975), and how easily new teachers automatically and inadvertently revert to teaching methods they experienced as students. It is not enough for preservice teacher education to help students reflect on their own experiences. We also need to help bridge those experiences to their future selves as teachers. To this end, a powerful part of our students' embodied learning was specifically connected to the ways they experienced their embodied self-concept of themselves as "student" and a 
"teacher" and how those were in conflict. The body connected them to an imaginative reflective capacity, offering insight into their assumptions and feelings about their work as students and teachers:

The biggest personal take away I had from these exercises was that myself as a student is in direct conflict with myself as a teacher ... . I do not feel it is possible to ask a student to do something that I do not model in some way, making this an important realization for how I approach aligning my values and practices.

Being in the body allowed this student to connect joy and creativity with the teacher he wants to be. In his body, he was better able to understand his negative experience of being a student and how different this was to what he wanted for his future students. His body spoke to him of potential lack of passion and joy in his student experiences. Another student also noted this:

Specifically, moving from my "student" pose to my "teaching" pose was a very eye-opening experience. . .Teachers must have a sense of the room, a sense of professionalism, a sense of openness and kindness, but also the ability to be stern. Sitting in my teacher's pose, without even one student in front of me, made me feel the weight of responsibility that rests on the shoulders of teachers. I can remember specifically thinking, "I am going to be responsible for not only the physical and mental well-being and safety of these children, but potentially their future as learners." That was a scary, but exciting prospect. I'm not sure I would have come to a realization like that without "embodying" a teacher.

As evidenced in this student's reflections, the body became a vehicle for preservice teacher learning about new roles and identities in a way traditional teacher education rarely does, by invoking the knowledge held in their bodies and emotional selves. Our students' experiences of learning by paying attention to their bodily-held sensations lent weight to the suggestion that embodied knowing is a distinctive kind of knowledge and that embodiment is a very particular process of coming to know (Freiler, 2008; Lawrence, 2012; Nguyen \& Larson, 2015). The reflective learning of placing preservice teachers in their bodies as students and then as teachers, juxtaposing theses identities and selves, was often powerful and multi-layered. Many seemed to feel the emotional and moral responsibility that this work would carry for them.

Reflections using emotions. We invited our students to draw on their emotional memories in reflecting on past experiences in classrooms. We saw this 
as a means of moving away from just privileging the mind, which is so often the focus in teacher education, instead integrating the emotions and body with the mind in a more holistic - or embodied — approach to learning and selfunderstanding (Satina \& Hultgren, 2001). We understand that some memories only emerge through embodied reflections. For example, when students were asked to move from constructing an image of themselves as a student to a teacher as we described earlier, they found themselves facing unexpected emotional memories. One student shared: "We were instructed to express the body language of our younger former student-selves and then how we would look as a future teacher. This brought out many different feelings for everyone. When channeling our past inner student, the majority of feelings included happy, depressed, angry, and anxious. Personally, I felt a feeling of discomfort and anxiety." When students were asked how the embodied reflective practices affected their thinking, another student reflected: "It made me experience a mixed range of feelings." We welcomed this aspect of our preservice teachers' reflections. Preservice teachers may experience a wide range of emotions (Bloomfield, 2010) and the emotional dimension of learning to teach is too often neglected in initial teacher education programs, perhaps because of instructors' discomfort about engaging with students about their emotions (Henry, 2013).

For some students, being asked to tap into emotions prompted them to think about what their own body language, appearance, and movements might unintentionally convey to their future students. One student in particular, who had had some past teaching experience, began to worry about what he had been inadvertently "communicating" to his students "through body language and facial expressions." He wondered: "Should I work to better conceal my emotions? Or alternatively, how can my body work with me to regulate my internal emotions?" This experience led him to question how much of himself he should bring into the classroom, a powerful and sophisticated line of inquiry that addresses some of the deeper complexities of teaching. Embodying emotion as a dimension of their reflective process seemed to open up deep avenues for our students' thinking about their roles and work as teachers. In this regard, our findings confirm Forgasz's (2014) dual claims about the "value of emotional pedagogical practices within teacher education ... [and] . . that theatrical embodiment is a worthy approach to producing such knowledge about emotion" (pp. 284-285).

\section{The Possibility of Using the Body to Teach}

Another frequently recurring theme in our preservice teachers' reflections related to their learning about the embodied presence of the teacher (Estola \& Elbaz-Luwisch, 2003) and how they might intentionally use their bodies to teach. 
We identified three interrelated categories of insight which we go on to discuss in turn: how teachers can communicate through body language, how bodies can influence the creation of a classroom community, and the inclusion of body and emotion as part of the teacher's toolkit to support student learning.

Body language in teaching. Many preservice teachers noted that embodied work made them more aware of their bodies in the classroom and the messages they conveyed. One student reflected, "Embodied cognition (embodied learning) is one particular theory that I had not given much thought to prior to this course but will be conscious of physical stance and position, posture, proximity and my movements throughout the classroom moving forward." On the simplest level, we speak to others through our bodies, convey energy, engagement, and connection through our stance. Another participant noted:

Using the embodied reflective practices also heavily influenced me. I never thought much about how the role of body language plays in teaching. It also shocked me to see just how much personality and insight you can gain from a person from just a simple pose.

Students were considering, possibly for the first time, how they were being "read" by others, how their bodies spoke to the world. One wrote, "It is not simply enough to think about the language and visual that you are trying to promote, but it is also essential to consider the way you are being received. The message you try to send is not always the one each student sees, and furthermore, each student may be reading it differently." Another noticed, ". . . I am still learning how to be a teacher in the sense of being aware of my embodiment. To do so, I must become more comfortable with myself, as students will be able to tell right away if I am feeling otherwise. Being aware of one's own embodiment is an important part of setting an overall positive mood within the classroom."

Many connected this work with their goals for themselves as teachers, "When I transformed to a teacher I really wanted to be engaging in a meaningful conversation because that is a way to connect with students. Using embodied reflective practices in class made me feel silly at first, but it really influenced my thinking as to how I want my students to perceive me." 
Once students were able to move past initial feelings of discomfort, many became open to transformative realizations and reflections:

I had never thought about how I used my body in communicating with students. Or, how my body was different while I was a student versus a teacher. The transition exercise from student to teacher that we performed, showed me that my teacher was actually talking to me as a student. As there will be many different students in my classroom, I need to make sure that I think about how to adjust my body to those different students. Not everyone will respond in the same way.

Creating a classroom community. The preservice teachers also noted the connection between their bodies and the classroom environment that they will create as teachers in the future. One write, "I took away from the embodied practice that body language plays a big role in the classroom setting. The way I arrange my classroom and move around in that space and the body language I use will have an impact on the learning taking place." In part, this is striking because in the vast literature on classroom management in teacher education, there is little about how the body helps to build a positive classroom community. Yet many of our students spoke of how clearly their bodies were part of this work. Many noted, "how I arrange my classroom, how I move around in that classroom, and what type of body language I use will all create a specific environment for my students." They realized how the body influences the way they build relationships with students:

The experience with Rachel [Forgasz] showed us that our body language could allow children to perceive you differently was extremely eye opening. It made me aware of how my body language needed to be inviting for children to feel like they could approach me for anything. Realization flowed through me as I recalled the uninviting postures of my least influential teachers. As a future teacher, I have to create a warm climate where my students could be excited and comfortable about learning in my class....

Building a community of learners also meant re-thinking how they position themselves in the classroom. One student noted: "The embodiment exercise . . . helped me realize the importance of my body language. Students will not feel comfortable if I display closed body language expressing a message of 'Not now' or 'Leave me alone." The experience of both being in his body and observations of embodied teaching and learning with others, led this preservice teacher to think about how bodies convey messages to students about how 
teachers want to be positioned.

The body as part of the teaching toolkit. Not only do our bodies act to convey something about who we are and help to construct our communities, they are a part of our teaching toolkit; we can support students' learning and meaning making through both using our bodies and helping students use their bodies. The teacher's body is part of what constitutes the act of teaching (Estola \& ElbazLuwisch, 2003) and the space between teacher and learners' bodies is where the pedagogical encounter resides (Dixon \& Senior, 2011). We saw some evidence that our students were beginning to see the body as part of their teaching toolkit, although the form this took was still limited. One student reflected: "The embodied teaching practice was very interesting. This was something I had never considered before, teaching as a physical act. I realize now that it is so important how we as teachers carry our physical bodies because it sets the tone for the rest of the class." Although this student is beginning to understand that the body is part of teaching, she remains focused on body language as contributing to tone and classroom community.

One of the preservice teachers used a visual to help illustrate the new understandings he developed about how to teach using the body (Figure 3):

Each person's embodied teacher was so easily interpreted as doing one specific thing. It makes me think that if this can so easily be identified by classmates, students in the classroom can pick up on this body language and adapt to what they think the teacher expects from the student, whether it is to listen, discuss, or interact as a group. I realize the importance of using body language to match my instructions and what I say that I expect in a classroom: 

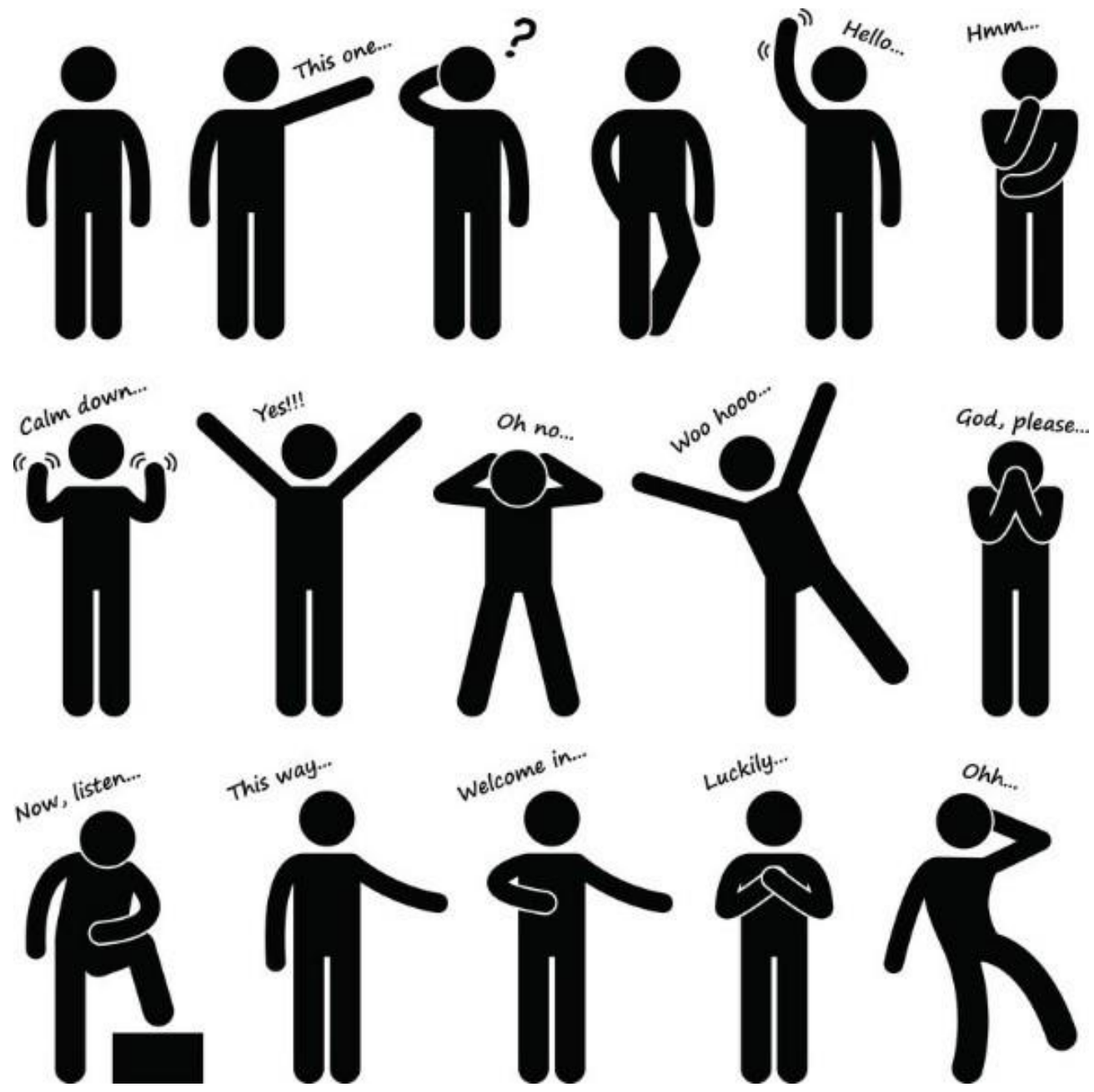

Figure 3. How to teach using the body

Here there is an acknowledgement that messages can be conveyed through the body. Although the above student was not yet able to see the body as central to teaching and learning content (noting its role in giving instructions, something tangential to the central focus of teaching), he understands that the body is a part of teaching. Nevertheless, as a number of our students noted, explorations of the role of the teacher's body are largely absent from teacher education courses. As one wrote, "Without this course, I don't think I would have reflected on the ways that teaching affects body language, or emotions. This is one detriment of learning how to teach in a classroom - maybe it doesn't prepare you for the use of your body or the way you'll feel while teaching." 
Perhaps the reason that the teacher's body is often absent from teacher education coursework is contained in this student's reflection on the whole experience:

Although I entered the activity questioning its validity and practicality in the classroom, I quickly realized these thoughts were only the product of socio-cultural pressures to temper bodily responses . . . . I have always been taught that what happens in the mind (i.e. reason, logic, etc.) should always be prioritized over those "base forces" that try to hijack our bodies, like feelings and emotions. Nevertheless, pedagogical embodiment quickly revealed to me that ... what happens in the mind influences the body and - perhaps, more importantly — what happens in the body influences the mind. Consequently, these activities made me more conscious of the ways in which my feelings or emotions are communicated through my physical appearance and presence ... In this way, I have come to better understand the connection between my mental and physical being.

Expressed in this student's reflections is the "artificial dichotomization" (Satina \& Hultgren, 2001, p. 552) of mind and body, and the related hierarchical privileging of mind over body and emotion that is the enduring legacy of Cartesian dualism (Lawrence, 2012; Stolz, 2014). Perhaps more interesting, though, is how effectively this student's long-standing, taken-for-granted assumptions were challenged by inviting him in to an embodied learning experience. After reflecting upon how this experience helped him better understand the role of the body in teaching and learning, he explored how he might need to tap into this kind of knowing with his students. He was becoming aware of how his students' bodies might also provide insight into their learning, understanding, and emotional experiences.

\section{Implications and Conclusions}

To truly re-conceptualize teacher education, we need new tools, structures, and epistemologies for understanding how teachers learn to be teachers. As teacher educators, we understand that our students require deep and continued engagement with ways of knowing that push beyond linguistic, positivist assumptions about teaching and learning. We are constantly re-imagining the boundaries for how to develop students as reflective practitioners, teaching them to interrogate and reassess their processes for coming to know. This action research study in particular highlights the complex, dynamic meanings preservice teachers can make by drawing on their embodied knowing in order to learn about teaching, to learn to teach, and to reflect on themselves as teachers and learners. 
Using embodied pedagogy in preservice teacher education supported our students to make the abstract concrete and felt. This was true for our students' own learning through their bodies and for their thinking about how they might use their bodies more intentionally as a dimension of their teaching practice.

Our study suggests that by engaging in reflective learning through their bodies, preservice teachers can promote self-understanding of themselves as learners and as prospective teachers, and broader-and deeper-reflective insights into their values, beliefs, and taken for granted assumptions. Reflective practice is a mainstay of many preservice teacher education programs but it is often difficult to move students beyond the surface levels of reflection towards deep, critical reflection that surfaces the taken for granted assumptions (Brookfield, 1995), beliefs, and emotions that unwittingly drive so much teacher decision making and action. This is hardly surprising since much reflective practice focuses on the logical-rational dimensions of thinking and action disconnected from the emotions. In our study, the deceptively simple act of embodying images of their student and teacher selves cut through the distractions of story and refocused attention on feeling, bringing conscious awareness to preservice teachers' (sometimes painful) emotional memories of their student days, their aspirations for themselves as teachers and for their future students, and the subsequent identification of the kinds of dispositions, behaviors, skills, and actions they would have to enact in order to achieve them. As suggested by our study, engaging preservice teachers in this kind of embodied reflection on the emotional dimensions of their student and teacher identities has great potential to surface otherwise subterranean assumptions, attitudes, and core beliefs that might otherwise go unarticulated yet deeply influence practice.

Such an outcome of embodied reflection should not be underestimated, chipping away as it does at the enduring problem of Lortie's (1975) decades-old apprenticeship of observation. By explicitly inviting preservice teachers to connect with, and to embody, their feelings as learners and as prospective teachers, we shine a light on the interaction between these two aspects of their identities. Regardless of whether it highlights contradiction, confluence, connection, or confusion, this embodied reflective practice places explicit attention on the idea that there is some kind of relationship between our student selves past and our teacher selves future, thereby disrupting the mindless reproduction of teacher practice at the heart of Lortie's problem.

A potential limitation of our study is that student data were generated in response to a single class activity undertaken right at the beginning of their teacher education program. But this very same fact sensitized us to just how 
powerful embodied reflection could be for teacher professional learning, especially when introduced at the very start of a teacher education program. In stark contrast to propositional knowledge about teaching so common to early preservice teacher education, these students began their learning by engaging in the experiential pedagogy of "feeling it in their bodies." As evinced in our data, this embodied approach enabled our students to very quickly access deep levels of self-understanding about their developing teacher identities. This suggests the potential value of beginning teacher education with embodied approaches in order to normalize body-based pedagogies and to legitimize the influence of emotional and embodied knowledge of, and on, teaching practice.

The other significant outcome of our study was that engaging in embodied reflection enabled our preservice teachers' growing appreciation of teaching itself as an embodied act. While were not really surprised by our preservice teachers' discomfort when engaging in an embodied pedagogy, we were somewhat taken aback to discover that the idea of teaching as an embodied act came as such a surprise to them. How could our students have been so oblivious to the embodied nature of teaching given the live, relational, interactive contexts of the schools and classrooms in which it takes place? Such unawareness is, arguably, a benign symptom of the hierarchical privileging of mind over body, other symptoms of which are the unfamiliarity and subsequent discomfort so commonly reported in research into embodied pedagogies (Forgasz \& McDonough, 2017; Lawrence, 2012; MacIntyre Latta \& Buck, 2008). At the same time, as teacher educators committed to anti-oppressive and socially just teaching, we recognise the problematic implications that follow.

A disembodied approach to teacher education can "abstract the individual [teacher] from her wider sociocultural and political context" (Forgasz and McDonough, 2017, p. 60), thereby legitimizing standardized approaches to teaching an assumed homogenous student mass. In contrast, embodied pedagogies such as those used in this study encourage awareness of the embodied presence that "anchors the otherwise objective [teacher] in the subjectivity of a particular physical context" (p. 16). The development and application of embodied critical pedagogies for anti-oppressive and socially just teacher education is an area of key interest for our future teaching and research collaborations. 


\section{References}

Anderson, G. L., Herr, K., \& Nihlen, A. S. (2007). Studying your own school: An educator's guide to practitioner action research. Thousand Oaks, CA: Corwin Press.

Ardoy, D. N., Fernandez-Rodriguez, J. M., Jimenez-Pavon, D., Castillo, R., Ruiz, J. R., \& Ortega, F. B. (2014). A physical education trial improves adolescents' cognitive performance and academic achievement: The EDUFIT study. Scandinavian Journal of Medicine and Science in Sports, 24(1), 52-61. Doi:10.1111/sms.12093

Bloomfield, D. (2010). Emotions and 'getting by': A pre-service teacher navigating professional experience. Asia-Pacific Journal of Teacher Education, 38(3), 221-234.

Brookfield, S. D. (1995). Becoming a critically reflective teacher. San Francisco: Jossey-Bass.

Chen, A.-G., Yan, J., Yin, H.-C., Pan, C.-Y., \& Chang, Y.-K. (2014). Effects of acute aerobic exercise on multiple aspects of executive function in preadolescent children. Psychology of Sport and Exercise, 15(6), 627636. Doi:10.1016/j.psychsport.2014.06.004

Coia, L. \& Taylor, M. (2017). Let's stay in the swamp: Poststructural feminist reflective practice. In R. Brandenburg, K. Glasswell, M. Jones \& J. Ryan (Eds.), Reflective theories in teacher education practices (pp. 4962). Dordrecht, The Netherlands: Springer Press.

Cutri, R.M., \& Whiting, E.F. (2015). The emotional work of discomfort and vulnerability. Teachers and Teaching: Theory and Practice, 21(8), 1010-1025.

Dewey, J. (1938). Experience and education. Indianapolis, IN: Kappa Delta Pi.

Dixon, C., \& Senior, M. (2011) Appearing pedagogy: From embodied learning and teaching to embodied pedagogy. Pedagogy, Culture \& Society, 19(3), 473-484. 
Estola, E. \& Elbaz-Luwisch, F. (2003). Teaching bodies at work. Journal of Curriculum Studies, 35(6), 697-719.

Fendler, L. (2003). Teacher reflection in a hall of mirrors: Historical influences and political reverberations. Educational Researcher 32(3), 16-25.

Forgasz, R. (2014). Reframing 'The Rainbow of Desire' as embodied selfreflexivity in initial teacher education. Research in Drama Education: The Journal of Applied Theatre and Performance, 19(3), 280-286.

Forgasz, R. (2015). Embodiment: A Multimodal International Teacher Education Pedagogy? International Teacher Education: Promising Pedagogies (Part C) (pp. 115-137).

Forgasz, R., \& McDonough, S. (2017). "Struck by the way our bodies conveyed so much:" A collaborative self-study of our developing understanding of embodied pedagogies. Studying Teacher Education, 13(1), 52-67. doi: $10.1080 / 17425964.2017 .1286576$

Freiler, T. (2008). Learning through the body. New Directions for Adult and Continuing Education, 119, 37-47. DOI: 10.1002/ace.304

Freire, P. (1970). Pedagogy of the oppressed. New York: Continuum.

Gao, Z., Hannan, P., Xiang, P., Stodden, D. F., \& Valdez, V. E. (2013). Video gamebased exercise, Latino children's physical health, and academic achievement. American Journal of Preventive Medicine, 44(3, Suppl 3), S240-S246. doi:10.1016/j.amepre.2012.11.023.

van Geel, M., Keuning, T., Visscher, A. J., \& Fox, J. P. (2016). Assessing the effects of a school-wide data-based decision-making intervention on student achievement growth in primary schools. American Educational Research Journal, 53(2), 360-394.

Ginns, I., Heirdsfield, A., Atweh, B., \& Watters, J. J. (2001). Beginning teachers becoming professionals through action research. Educational Action Research, 9(1), 111-33.

Gitlin, A., Barlow, L, Brubank, M. D., Kauchak, D., \& Stevens, T. (1999). Preservice teachers' thinking on research: Implications for inquiry oriented teacher education. Teaching and Teacher Education 15, 753-769. 
Goodnough, K. (2010). The role of action research in transforming teacher identity: Modes of belonging and ecological perspectives. Educational Action Research, 18(2), 167-182.

Henry, S. E. (2013). Vulnerability and emotional risk in an educational philosophy. Emotion. Space and Society, 8, 11-17.

Herr, K. (1999). Unearthing the unspeakable: When teacher research and political agendas collide. Language Arts, 77(1), 10-15.

Ladson-Billings, G. (1995). But that's just good teaching: The case for culturally relevant pedagogy. Theory into Practice 34(3), 159-165.

Lawrence, R. L. (2012). Coming full circle: Reclaiming the body. New Directions for Adult and Continuing Education, 134 (Summer), 71-78.

Lortie, D. (1975). Schoolteacher: A sociological study. Chicago: University of Chicago Press.

Loughran, J. J. (2002). Effective reflective practice: In search of meaning in learning and teaching. Journal of Teacher Education 53(1), 33-43.

Macintyre Latta, M., \& Buck, G. (2008). Enfleshing embodiment: "Falling into trust" with the body's role in teaching and learning. Educational Philosophy and Theory: Incorporating ACCESS, 40(2), 315-329.

Mandinach, E. B., \& Jimerson, J. B. (2016). Teachers learning how to use data: A synthesis of the issues and what is known. Teaching and Teacher Education, 60, 452-57.

Mertler, C. A. (2011). Action research: Improving schools and empowering educators. New York: Sage.

McNiff, J. (2010). Action research for professional development: Concise advice for new and experienced action researchers. Dorset, England: September Books.

Mills, G. E. (2011). Action research: A guide for the teacher researcher, 4th ed. Boston, MA: Pearson Publications. 
Nguyen, D. J., \& Larson, J. B. (2015). Don't forget about the body: Exploring the curricular possibilities of embodied pedagogy. Innovative Higher Education, 40(4), 331-344. DOI: 10.1007/s10755-015-9319-6

Noguera, P. A. (2003). The trouble with black boys: The role and influence of environmental and cultural factors on the academic performance of African American males. Urban Education 38(4), 431-459.

Opfer, V. D., \& Pedder, D. (2011). Conceptualizing teacher professional learning. Review of Educational Research, 81(3), 376-407.

Pagis, M. (2009). Embodied self reflexivity. Social Psychology Quarterly, 72(3), 265-283.

Price, J. (2001). Action research, pedagogy and change: the transformative potential of action research in pre-service teacher education. Journal of Curriculum Studies, 33(1), 43-74.

Reeves, T. D., Summers, K. H., \& Grove, E. (2016). Examining the landscape of teacher learning for data use: The case of Illinois. Cogent Education, 3(1), 1-21. Doi:10.1080/2331186X.2016.1211476

Richardson, V. (1990). The evolution of reflective teaching and teacher education. In R. T. Clift, R. W. Houston \& M. C. Pugach (Eds), Encouraging Reflective Practice in Education: an analysis of issues and programs, (pp. 3-19). New York: Teachers College Press.

Satina, B., \& Hultgren, F. (2001). The absent body of girls made visible: Embodiment as the focus in education. Studies in Philosophy and Education, 20(6), 521-534.

Schön, D. A. (1995). Knowing-in-action: The new scholarship requires a new epistemology. Change: The Magazine of Higher Learning, 27(6), 27-34, DOI:10.1080/00091383.1995.10544673

Senior, K., \& Dixon, M. (2009). Reading with the ancients: Embodied learning and teaching to an embodied pedagogy? ACCESS: Critical Perspectives on Communication, Cultural \& Policy Studies, 8(2), 21-30. 
Smith, K., \& Sela, O. (2005). Action research as a bridge between pre-service teacher education and in-service professional development for students and teacher educators. European Journal of Teacher Education, 28(3), 293-310.

Somekh, B. \& Zeichner, K. (2009). Action research for educational reform: remodeling action research theories and practices in local contexts. Educational Action Research, 17(1), 5-21.

Stolz, S. A. (2014). Embodied learning. Educational Philosophy and Theory, 47(5), 474-487. DOI: 10.1080/00131857.2013.879694

Taylor, M. \& Coia, L. (2009). Co/autoethnography: Investigating teachers in relation. In C. Lassonde, S. Gallman \& C. Kosnik (Eds.), Self-Study research methodologies for teacher educators (pp. 169-186). Rotterdam, The Netherlands: Sense Publishers.

Vygotsky, L. S. (1978). Mind in society. Cambridge, MA: Harvard University Press.

Zembylas, M. (2010). Teachers' emotional experiences of growing diversity and multiculturalism in schools and the prospects of an ethic of discomfort. Teachers and Teaching, 16(6), 703-716. 